\title{
Biskuit mocaf-garut tinggi zat besi meningkatkan kadar Fe darah dan kadar hemoglobin pada tikus Sprague Dawley
}

\author{
Hesti Permata Sari*, Friska Citra Agustia, Yovita Puri Subardjo, Gumintang Ratna Ramadhan
}

\begin{abstract}
Background: One of the most popular type of snack is biscuit, which was favoured by all-ages including toddler. At 2016, previous study has found formulation of biscuit made from mocaf-arrowroot substituted with chicken's liver and red spinach (Mogatiyam) that has high level of iron for anemic toddlers.

Objectives: This research aimed to measure the bioassay values of Mogatiyam biscuit in anemic rats.

Methods: This is a true experimental study using 32 Sprague Dawley male rats aged 3 weeks induced-anemia using zero iron feed for 7 days. The rats were randomly divided into 4 treatment groups, which are $1 / 2$ serving biscuit (0.2 gram), 1 serving (0.8 gram) and 2 servings (0.4 grams). Statistical analysis was performed using ANOVA to identify the increase change in each group, and LSD to identify the best treatment.

Results: The result reported significant differences in Fe and hemoglobin after biscuit feeding between groups (p=0.00). The best treatment was found in group P3 (2 servings of biscuit) with Fe and hemoglobin increase were $6.65 \pm 0.49 \mu \mathrm{g} / \mathrm{dl}$ and 3.62 $\pm 0.06 \mathrm{gr} / \mathrm{dl}$ respectively.

Conclusion: Biscuit made for anemic toddler from mocaf-arrowroot substituted with chicken's liver and red spinach (mogatiyam) can increase blood Fe and haemoglobin in anemic rat.
\end{abstract}

Keywords : anemia, biscuits, haemoglobin, iron, rats

\section{ABSTRAK}

Latar Belakang : Biskuit merupakan bentuk snack yang digemari semua usia terutama balita. Pada tahun 2016, telah dihasilkan produk biskuit tinggi besi yang berbahan dasar tepung mocaf dan garut dengan penambahan hati ayam dan bayam merah (mogatiyam) yang ditujukan untuk balita anemia.

Tujuan: Melakukan pengujian bioassay biskuit berbahan dasar mocaf-garut yang disubtitusi hati ayam dan bayam merah (mogatiyam) pada tikus anemia.

Metode : Sebanyak 32 tikus Sprague Dawley jantan berusia 3 minggu dibuat anemia melalui pakan tanpa zat besi selama 7 hari dan dilanjutkan perlakuan selama 14 hari, dibagi menjadi 4 kelompok perlakuan, yaitu pakan biasa, pakan biasa dan biskuit 1/2 takar saji (0,2 gram), pakan biasa dan 1 takar saji (0,8 gram) serta pakan biasa dan 2 takar saji (0,4 gram). Analisis statistik ANOVA untuk menguji perbedaan kenaikan tiap kelompok dan LSD untuk mengetahui perlakuan terbaik.

Hasil : terdapat perbedaan kenaikan nilai fe darah dan hemoglobin yang bermakna setelah pemberian biskuit untuk setiap kelompok $(p=0,00)$. Perlakuan terbaik adalah kelompok P3 dengan kenaikan nilai Fe darah dan hemoglobin tertinggi $(6,65 \pm$ $0,49 \mu \mathrm{g} / \mathrm{dl} ; 3,62 \pm 0,06 \mathrm{gr} / \mathrm{dl})$

Kesimpulan : Pemberian biskuit biskuit balita berbahan dasar mocaf-garut yang disubtitusi hati ayam dan bayam merah (mogatiyam) dapat meningkatkan nilai Fe darah dan Hb tikus anemia.

Kata Kunci : anemia, biscuit, hemoglobin, zat besi, tikus

\section{PENDAHULUAN}

Jumlah balita anemia di Indonesia masih cukup tinggi. Berdasar Riskesdas 2013, sebanyak 28,1\% anak usia 12-59 bulan mengalami anemia. Hasil Survey Kesehatan Rumah Tangga (SKRT) tahun 2012 juga menyebutkan bahwa persentase balita yang mengalami anemia yakni sebesar $40,5 \%$. Anemia adalah keadaan dengan kadar hemoglobin, hematokrit dan sel darah merah yang lebih rendah dari nilai normal. Berdasarkan hasil Riskesdas 2007 salah satu faktor utama penyebab anemia pada balita adalah defisiensi asupan zat besi (anemia mikrositik hipokromik) yaitu mencapai $70,1 \%$. Zat besi (Fe) merupakan zat yang esensial bagi tubuh dan diperlukan dalam hematopoesis (pembentukan darah), yaitu dalam mensintesa hemoglobin. ${ }^{1}$

Salah satu solusi potensial yang bisa dikembangkan untuk mengatasi masalah anemia defisiensi besi pada balita adalah dengan peningkatan konsumsi sumber makanan tinggi zat besi. Biskuit adalah salah satu bentuk cemilan yang digemari semua usia terutama balita. Pada tahun 2016, Agustia et al telah menghasilkan produk biskuit tinggi besi yang berbahan dasar tepung mocaf dan garut dengan penambahan hati ayam dan bayam merah (mogatiyam) yang ditujukan untuk balita. ${ }^{2}$

Program Studi Ilmu Gizi, Fakultas Ilmu - ilmu Kesehatan, Universitas Jenderal Soedirman. Jl. Dr. Suparno, Karangwangkal, Purwokerto Utara, Banyumas, 
Kandungan pati mocaf yang tinggi dapat digunakan untuk substitusi tepung terigu dalam pembuatan biskuit. ${ }^{3}$ Pati garut memiliki daya kembang yang tinggi, yaitu $54 \%$ dan nilai cerna pati $84,35 \%$ sehingga menghasilkan biskuit yang lebih lembut, renyah dan mudah dicerna. ${ }^{4}$ Hati ayam buras mengandung zat besi $24,94 \mathrm{mg} / 100$ g. ${ }^{5}$ Kandungan protein yang tinggi pada hati $( \pm 15 \mathrm{~g} / 100 \mathrm{~g})$ berperan dalam meningkatkan absorbsi zat besi nonheme, pembentuk sel darah merah dan untuk mempertahankan tekanan osmosis darah. Bayam merah juga mengandung vitamin $\mathrm{C}$ cukup tinggi sehingga sesuai untuk ditambahkan pada biskuit yang mengandung zat besi tinggi. Vitamin $\mathrm{C}$ akan membantu penyerapan zat besi dalam tubuh. Dalam 1 sajian (22,8 gram) biskuit tersebut memiliki kandungan zat besi sebesar 3,2 mg atau dapat memenuhi $35,5 \%$ - 40\% kebutuhan besi balita. $^{2}$

Keunggulan lain yang dimiliki biskuit mocafgarut selain dapat memenuhi kebutuhan zat gizi balita yaitu bahan-bahan yang digunakan adalah bahan pangan lokal. Bahan lokal tersebut setelah diolah menjadi biskuit cenderung lebih disukai balita dibandingkan dengan konsumsi bahan tersebut secara langsung dengan teknik pemasakan biasa seperti direbus. Biskuit mocaf-garut telah memenuhi standar minimal kandungan gizi biskuit PMT dan memiliki keunggulan dalam kandungan zat besi yaitu $54,4 \%{ }^{2}$ Penelitian ini bertujuan mengkaji pemanfaatan biskuit berbahan dasar tepung mocaf dan garut yang disubstitusi bahan makanan tinggi besi yaitu hati ayam dan bayam merah terhadap pemulihan status anemia tikus.

\section{BAHAN DAN METODE}

Penelitian ini merupakan penelitian eksperimental laboratorium dengan jenis pre-post test randomized control group design. Metode yang digunakan adalah metode deplesi-replesi hemoglobin. Penelitian dilaksanakan pada bulan Mei-Juni 2017 di Laboratorium Pusat Studi Pangan dan Gizi PAU (Pusat Antar Universitas) Universitas Gadjah Mada Yogyakarta.

Sebanyak 32 ekor tikus (Rattus norvegicus galur Sprague Dawley) berjenis kelamin jantan berusia 4 minggu dengan berat rata-rata 100 gram. Dikondisikan menjadi anemia dengan cara memberikan pakan standar tanpa besi selama 7 hari sehingga tikus mengalami anemia. Parameter anemia yang digunakan dalam penelitian ini adalah ketika kadar hemoglobin tikus kurang dari $10 \mathrm{~g} / \mathrm{dl}$ dan kadar Fe darah kurang dari 80 $\mu \mathrm{g} / \mathrm{dl}$.
Hewan coba dibagi kedalam 4 kelompok secara random sampling. Dosis yang diberikan pada tikus dikonversi dari manusia yaitu 22,8 gram $^{5}$ dengan memperhitungkan berat badan tikus, sehingga didapatkan dosis seperti pada Tabel 1 .

Tabel 1. Dosis Biskuit untuk Sekali Pemberian

\begin{tabular}{ccc}
\hline $\begin{array}{c}\text { Kelompok } \\
\text { Perlakuan }\end{array}$ & $\begin{array}{c}\text { Takar } \\
\text { Saji }\end{array}$ & $\begin{array}{c}\text { Dosis Pemberian Perhari } \\
\text { (per 200 gram Berat Tikus) }\end{array}$ \\
\hline K1 & 0 & $0 \mathrm{~g}$ \\
P1 & 0,5 & $0,2 \mathrm{~g}$ \\
P2 & 1 & $0,4 \mathrm{~g}$ \\
P3 & 2 & $0,8 \mathrm{~g}$ \\
\hline
\end{tabular}

Pemberian biskuit berbahan dasar tepung mocaf dan garut yang disubtitusi bahan makanan tinggi besi yaitu hati ayam dan bayam merah (mogatiyam) dilakukan selama 14 hari dengan cara disonde. Semua kelompok baik kelompok perlakuan maupun kontrol diberikan pakan standar yaitu AIN-93 secara adlibitum. Pada hari ke-15 masa perlakuan, tikus diambil darahnya sebanyak $1 \mathrm{ml}$ melalui mata (medial canthus sinus orbitalis) untuk dianalisis kadar $\mathrm{Hb}$ dan $\mathrm{Fe}$ darah. Pengujian $\mathrm{Fe}$ menggunakan metode Nitro-Paps sedangkan kadar $\mathrm{Hb}$ diukur dengan metode cyanmethemoglobin. Hasil penelitian dianalisis dengan ANOVA dan LSD. Protokol penelitian ini telah di telaah oleh tim komisi etik Fakultas Kedokteran Universitas Jenderal Soedirman dengan nomor Ref: 1432/KEPK/IV/2017.

\section{HASIL}

Masa deplesi 7 hari dengan pemberian pakan standar tanpa $\mathrm{Fe}$ telah mampu menurunkan nilai $\mathrm{Fe}$ darah dan $\mathrm{Hb}$ tikus anemia. Setelah masa perlakuan 14 hari, terjadi peningkatan nilai Fe darah dan hemoglobin pada hewan coba yang diberi tambahan makanan biskuit mogatiyam. Peningkatan tertinggi nilai $\mathrm{Fe}$ darah dan $\mathrm{Hb}$ ditunjukkan pada kelompok yang diberi dosis 2 takar saji biskuit tinggi besi yang berbahan dasar tepung mocaf dan garut dengan penambahan hati ayam dan bayam merah $(3,62 \pm 0,06 \mathrm{gr} / \mathrm{dl}$ dan $6,65 \pm$ $0,49)$. Tidak terdapat kenaikan yang bermakna pada kelompok yang tidak diberi tambahan biskuit (Tabel 2 dan 3)

Hasil analisis statistik paired t-test menunjukkan bahwa terdapat perbedaan yang bermakna antara kadar hemoglobin sebelum dengan setelah intervensi pada kelompok P1, P2, dan P3 ( $p=0,001 ; p<0,05)$. Biskuit ini dapat memperbaiki status anemia pada tikus. Kelompok P1, P2 dan P3 di akhir perlakuan memiliki nilai Fe darah diatas $80 \mu \mathrm{g} / \mathrm{dl}$ dan $\mathrm{Hb}$ diatas $10 \mathrm{mg} / \mathrm{dl}$. 
Tabel 2. Nilai Fe Darah Hewan Coba Masa Deplesi dan Setelah Diberi Biskuit Tinggi Besi

\begin{tabular}{crrrrr}
\hline \multirow{2}{*}{ Kelompok } & \multicolumn{3}{c}{ Fe $(\boldsymbol{\mu g} / \mathbf{d l})$} & \multirow{2}{*}{ Dependet t-tets } & \multirow{2}{*}{ One way ANOVA } \\
\cline { 2 - 4 } & Pre & Pos & Delta & & 0,001 \\
K1 & $67,90 \pm 3,17$ & $69,12 \pm 3,02$ & $1,00 \pm 0,51$ & 0,180 & 0,001 \\
P1 & $71,59 \pm 5,49$ & $90,63 \pm 5,91$ & $4,29 \pm 0,99$ & 0,001 \\
P2 & $71,91 \pm 3,89$ & $104,76 \pm 2,70$ & $5,72 \pm 0,40$ & 0,001 \\
P3 & $74 \pm 3,21$ & $118,43 \pm 6,25$ & $6,65 \pm 0,49$ & \\
\hline
\end{tabular}

Tabel 3. Nilai Hb Hewan Coba Masa Deplesi dan Setelah Diberi Biskuit Tinggi Besi

\begin{tabular}{|c|c|c|c|c|c|}
\hline \multirow[t]{2}{*}{ Kelompok } & \multicolumn{3}{|c|}{ Hb (gr/dl) } & \multirow{2}{*}{ Dependet t-tets } & \multirow{2}{*}{ One way ANOVA } \\
\hline & Pre & Pos & Delta & & \\
\hline K1 & $9,67 \pm 0,17$ & $9,67 \pm 0,17$ & $-0,0043 \pm 0,07$ & 0,837 & 0,001 \\
\hline $\mathrm{P} 1$ & $9,50 \pm 0,28$ & $10,42 \pm 0,22$ & $0,92 \pm 0,07$ & 0,001 & \\
\hline $\mathrm{P} 2$ & $9,41 \pm 0,42$ & $11,67 \pm 0,38$ & $2,26 \pm 0,06$ & 0,001 & \\
\hline P3 & $9,41 \pm 0,27$ & $13,03 \pm 0,26$ & $3,62 \pm 0,06$ & 0,001 & \\
\hline
\end{tabular}

Hasil uji ANOVA menunjukkan bahwa perlakukan pemberian biskuit berbahan dasar mocafgarut dengan substitusi hati ayam dan bayam merah ${ }^{5}$ menghasilkan kenaikan kadar Fe darah dan hemoglobin yang berbeda untuk setiap kelompok $(p=0,00)$. Hasil uji Post-Hoc DMRT (Duncan's Multiple Range Test) menunjukkan kelompok P3 menempati subset keempat dengan nilai tertinggi. Hal ini memperlihatkan kelompok P3 merupakan jumlah pemberian yang paling baik dalam meningkatkan kadar $\mathrm{Fe}$ darah dan hemoglobin tikus anemia, kemudian diikuti kelompok P2, P1, dan terakhir kontrol.

\section{PEMBAHASAN}

Selama masa deplesi, tikus diberi pakan standar yang telah dihilangkan kandungan besinya sehingga tikus mengalami anemia. Anemia defisiensi besi terjadi akibat sedikit atau tidak adanya asupan besi yang mengakibatkan kosongnya cadangan besi tubuh (depleted iron store) sehingga penyediaan besi untuk pembentukan hemoglobin menjadi berkurang. Defisiensi asupan zat besi memberikan kontribusi paling besar terhadap kejadian anemia dibandingkan dengan defisiensi asupan zat gizi lainnya sebesar $65,85 \%$. $^{7}$

Masa replesi melalui pemberian makanan tambahan berupa biskuit berbahan dasar tepung mocaf dan garut dengan penambahan hati ayam dan bayam merah yang ditujukan untuk balita mampu menaikan kadar Fe darah dan hemoglobin tikus anemia. Semakin tinggi jumlah yang diberikan, semakin tinggi pula peningkatan kadar $\mathrm{Fe}$ darah dan hemoglobin yang terjadi. Peningkatan ini berkaitan dengan kandungan yang terdapat pada biskuit ini. Selain mengandung kadar zat besi yang tinggi, biskuit ini juga mengandung kadar protein yang cukup tinggi. ${ }^{5}$

Kandungan zat besi dalam biskuit berbahan dasar tepung mocaf dan garut dengan penambahan hati ayam dan bayam merah ini cukup tinggi, yaitu mampu mencukupi kebutuhan besi balita sebanyak 35,5\% $40 \%$ dalam satu takar saji. Sintesis hemoglobin memerlukan ketersediaan zat besi dan protein yang cukup didalam tubuh. ${ }^{8}$ Zat besi $(\mathrm{Fe})$ merupakan mineral yang penting bagi tubuh karena fungsinya dalam hematopoesis, yaitu dalam mensintesa hemoglobin. Zat besi (Fe) merupakan mikroelemen yang esensial bagi tubuh. Zat besi terutama diperlukan dalam hematopoesis (pembentukan darah), yaitu dalam mensintesa hemoglobin. Tubuh tidak dapat memproduksi zat besi sendiri, pemenuhan zat besi dalam tubuh didapatkan dari asupan. Jumlah asupan zat besi akan berpengaruh terhadap peningkatan produksi hemoglobin.

Protein diketahui berperan penting dalam transportasi zat besi di dalam tubuh, bila tidak tersedia protein dalam jumlah cukup dalam tubuh maka zat besi yang diasup tidak dapat didistribusikan dengan ke organ. Protein yang berfungsi untuk transportasi zat besi yaitu transferrin. Transferin adalah suatu glikoprotein yang disintesis di hati. Protein ini berperan sentral dalam metabolisme besi tubuh sebab transferin mengangkut besi dalam sirkulasi ke tempat - tempat yang membutuhkan besi, seperti dari usus ke sumsum tulang untuk membentuk hemoglobin yang baru.

Bahan subtitusi yang memperkaya biskuit berbahan dasar tepung mocaf dan garut ini adalah bayam merah dan hati ayam. Bahan makanan merupakan bahan makanan yang mudah didapatkan dengan harga yang relatif terjangkau. Beberapa penelitian menunjukkan subtitusi biskuit dengan bahan tinggi besi dapat meningkatkan nilai $\mathrm{Hb}$ hewan coba. Mahmoed et al (2009) juga menyatakan bahwa biskuit gandum yang disuplementasi tepung biji fenugreek yang memiliki kandungan zat besi yang tinggi mampu meningkatkan kadar hemoglobin tikus anemia ${ }^{9}$, lebih lanjut Widjinindyah et al (2012) juga menyatakan bahwa anemia defisiensi besi dapat ditangani dengan pemberian bahan makanan alami seperti dalam penelitiannya menggunakan tepung daun kelor. ${ }^{10}$ 
Bayam merah sebagai bahan subtitusi biskuit berbahan dasar tepung mocaf dan garut diketahui memiliki kandungan zat besi tertinggi dibanding jenis bayam yang lain. Zat besi dalam bayam merah termasuk kedalam jenis besi non heme $\left(\mathrm{Fe}^{3+}\right)$, yaitu jenis yang susah di absorbsi. Zat Besi dalam bayam merah yang akan diserap harus direduksi dari bentuk feri $\left(\mathrm{Fe}^{3+}\right)$ ke fero $\left(\mathrm{Fe}^{2+}\right)$, proses reduksi ini terbantukan oleh adanya kandungan vitamin $\mathrm{C}$ yang juga terdapat dalam bayam merah itu sendiri. Selain mengandung zat besi yang tinggi, bayam merah juga mengandung vitamin C yang cukup tinggi, yaitu $730 \mathrm{mg}$ per 100 gram daun bayam. ${ }^{11}$ Pandey et al menyatakan bahwa pemberian dosis ekstrak bayam spesies Amaranthus cruentus pada tikus anemia mampu mengembalikan secara signifikan kadar sel darah merah, sel darah putih, dan hemoglobin tikus percobaan. ${ }^{12}$ Hal inilah yang membuat biskuit berbahan dasar berbahan dasar tepung mocaf dan garut dengan penambahan hati ayam dan bayam merah meningkatkan kadar $\mathrm{Fe}$ darah dan hemoglobin pada tikus anemia.

Hati ayam yang terkandung didalam biskuit ini juga mengandung zat besi yang tergolong tinggi. Hati ayam merupakan sumber zat besi heme. Berdasarkan sumbernya, bentuk zat besi dibagi menjadi dua macam, yaitu besi heme yang diperoleh dari makanan hewani dan besi non-heme yang berasal dari makanan nabati. Besi-heme merupakan bagian dari hemoglobin dan myoglobin yang terdapat didalam daging hewan dan dapat diserap dua kali lipat dibandingkan dengan besi non-heme.

Hasil penelitian menunjukkan bahwa biskuit balita berbahan dasar berbahan dasar tepung mocaf dan garut dengan penambahan hati ayam dan bayam merah ini dapat memperbaiki kadar Fe darah dan hemoglobin pada tikus anemia secara signifikan. Hal ini dapat menjadi alternatif baru cara penangan balita anemia. Dampak defisiensi besi pada balita adalah terjadinya perubahan pada fungsi kognitif, perkembangan motorik dan perkembangan mental dan perilaku. ${ }^{13}$ Dibandingkan dengan anak yang sehat, anak dengan defisiensi zat besi lebih mudah lelah, ragu-ragu, kurang aktif, kurang memperhatikan perintah dan peragaan, dan cenderung menempel pada pengasuh. ${ }^{14,15}$ Dengan adanya hasil penelitian ini, diharapkan para pemegang kebijakan dapat mencoba alternatif penangan masalah anemia pada balita yang selama ini hanya berkutat pada pemberian suplemen tablet besi. Penelitian ini telah mampu membuktikan manfaat biskuit balita mogatiyam dalam mengatasi anemia pada tikus.

\section{SIMPULAN}

Biskuit balita berbahan dasar berbahan dasar tepung mocaf dan garut dengan penambahan hati ayam dan bayam merah mampu meningkatkan kadar Fe darah dan hemoglobin pada tikus anemia. Pemberian sebanyak 2 takar saji (12 keping biskuit) dalam 1 hari menunjukkan hasil yang lebih baik daripada 1 takar saji. Diharapkan penelitian selanjutnya dapat melakukan uji bioassay biskuit ini pada balita.

\section{DAFTAR PUSTAKA}

1. Gropper SS, Smith JL, Groff JL. Advanced nutrition and human metabolism 5th ed. Canada: Wadsworth, Cengange Learning; 2009.

2. Agustia FC, Subardjo YP, Sari HP. Pengembangan biskuit MOCAF-Garut dengan substitusi hati sebagai alternatif biskuit tinggi zat besi untuk balita. Jurnal Gizi dan Pangan. 2017;12(2):129138.

3. Subagjo A, Witono Y, Fahmi F. 2008. Prosedur Operasi Standar (POS) Produksi Mocaf Berbasis Kluster. Trenggalek: Kementerian Negara Riset dan Teknologi:1-5.

4. Aini N, Wirawani N. 2013. Kontribusi MP-Asi biskuit substitusi tepung garut, kedelai, dan ubi jalar kuning terhadap kecukupan protein, vitamin A, kalsium, dan Zink pada bayi. Journal of Nutrition College. 2(4):458-466.

5. Simbolon DOS, Masfria, Sudarmi. 2012. Pemeriksaan kadar Fe dalam hati ayam ras dan ayam buras secara spektrofotometri serapan atom. J Nat Prod Pharma Chemi. 1(1):8-13.

6. Huma N, Rehman SU, Anjum FM, Murtaza MA. 2007. Food fortifcation strategy: preventing iron defciency anemia : A review. Crit Rev Food Sci Nutr. 47(3):259-265

7. Wijaya C. Hubungan asupan zat gizi dengan kejadian anemia pada anak usia 6-23 bulan di Kabupaten Aceh Besar tahun 2011. Skripsi, Universitas Indonesia; 2012. unpublished

8. Susilo J, Hamam H. Hubungan asupan zat besi dan inhibitornya sebagai prediktor kadar hemoglobin ibu hamil di Kabupaten Bantul Propinsi DIY, Berita Kedokteran Masyarakat 18 (1) : 1-8. 2009.

9. Mahmoed.I. Ibrahium and A.I. Hegazy. Iron Bioavailability of Wheat Biscuit Supplemented by Fenugreek Seed Flour. World Journal of Agricultural Sciences 5 (6): 769-776, ISSN 18173047. 2009

10. Widjindyah A, Anwar S, Susetyowati SH. Pemanfaatan tepung daun kelor (Moringa oleifera Lamk) dengan pretreatment asam dan tepung ikan lele terhadap pemulihan anemia secara in vivo. Jurnal Gizi Klinik Indonesia IX(2); 2012

11. Persatuan Ahli Gizi Indonesia (Persagi). Tabel Komposisi Pangan Indonesia. Jakarta: PT. Elex Media Komputindo, Kompas Gramedia; 2009. 
12. Pandey S, Ganeshpurkar A, Bansal D, Dubey N. Hematopoietic Effect of Amaranthus cruentus Extract on Phenylhydrazine-Induced Toxicity in Rats. J Diet Suppl. 2016 Nov;13(6):607-15. doi: 10.3109/19390211.2016.1155685. 2016.

13. Carter RC, Jacobson JL, Burden MJ, ArmonySivan R, Dodge NC, Angelilli ML, Lozoff B, Jacobson SW. Iron deficiency anemia and cognitive function in infancy. Pediatrics. Volume 126, Number 2; 2010.
14. Schneider JM, Fujii ML, Lamp CL, Lonnerdal B, Dewey KG, Zidenberg-Cherr S. Anemia, iron deficiency, and iron deficiency anemia in 12-36mo-old children from low-income families. Am J Clin Nutr. 82:1269-75; 2005

15. Milman, N. Anemia-Still a major health problem in many parts of the world. Ann Hematol. 90: 369$377 ; 2011$. 